УДК 141:123.1

https://orcid.org/0000-0001-5952-7278

\title{
СВОБОДА ЯК ОСНОВА ФІЛОСОФІї ЛЬВА ШЕСТОВА
}

Т. Прудка, аспірант кафедри філософії, соціально-політичних і правових наук Донбаського державного педагогічного університету, м. Слов'янськ

Філософія Льва Шестова має тісний взаємозв'язок з життям. Мислитель вважав за необхідне приділяти увагу найбільш актуальним питанням, одним з яких є проблема свободи.

У статті аналізується феномен свободи як основоположний принции філософії Шестова. Також відображені основні філософські ідеї мислителя, аналізується взаємозв'язок релігії та філософії в його творчості.

Відзначається, що свобода для Шестова має центральне значення. Без неї немає $i$ не може бути справжньої філософії. При иььоу Шестов зауважує, щуо логіка є основним противником свободи. У статті аналізується аргументація Шестова з иього питання.

Підкреслюється, щуо віру в Бога філософ ставить вище за розум, оскільки Бог - ие Істина, а розуму людини властиво блукати.

Також виявлено, щчо Шестов вважав неможливим раціонально судити про сенс світобудови. Філософ стверджує, щзо логіка не може бути єдиним способом пізнання буття, він шукає інші форми проникнення в таємниці світобудови. Таким засобом стає для нього віра в Бога. Тільки віра дає можливість осягнути таємниці світу.

Шестов передбачив основні ідеї пізнього екзистенщіалізму. Філософа хвилювали проблеми індивідуального людського існування, пошук виходу з безнадійності.

Ключові слова: свобода, віра, Бог, істина, розум, логіка, необхідність, філософія.

Постановка й обгрунтування актуальності проблеми. Філософія Льва Шестова відрізняється свободою думки, вона своєрідна та надзвичайна. Але, на жаль, його творчості присвячено не дуже багато робіт. Ми вважаємо, що філософія Шестова потребує детального вивчення. Саме це зумовило актуальність цієї роботи.

Аналіз наукових досліджень. Серед дослідників творчості Шестова можна назвати М. Бредяєва, який був давнім другом філософа. Він присвятив йому декілька праць: «Фундаментальна ідея філософії Льва Шестова», «Лев Шестов і К'єркегор» та інші.

Також творчість Шестова вивчали відомі філософи В. В. Зеньковский, М.О. Лоський.

Н. Мотрошилова присвятила філософу книгу «Лев Шестов і западна філософія», статтю «Парабола життєвої долі Льва Шестова» [3] й інші роботи. 
Серед закордонних дослідників відомі Б. Фондане «Бесіди зі Львом Шестовим», Е. Левинас «К'єркегор та екзистенціальна філософія Леона Честова», Чеслав Мілош «Шестов, або Чистота відчаю», Гжегож Груца «Філософія кризи Льва Шестова», «Образ людини в філософії Льва Шестова», Майкл Финкенталь «Лев Шестов: екзистенціальний філософ та релігійний мислитель» [6], Б. Мартін «Антологія Шестова» [7] та інші.

\section{Виокремлення аспектів проблеми, які ще недостатньо вивчені.}

Творчості Льва Шестова приділялося недостатньо уваги, і ми вважаємо, що його філософія потребує ретельного вивчення. Наше завдання полягає в тому, щоб визначити основні ідеї мислителя стосовно феномену свободи.

Формулювання мети статті. Мета дослідження полягає в тому, щоб виявити значення свободи як основи філософії Льва Шестова.

Виклад основного матеріалу. Лев Ісаакович Шестов (Шварцман) (1866-1938) - видатний філософ i літератор, представник релігійнофілософського відродження початку XX ст. Свою філософію визначав як релігійну і екзистенціальну. Виняткову роль в становленні його світогляду зіграли, поряд із Шекспіром, якого він називав своїм першим учителем філософії, Достоєвський і Толстой.

Особливу метафізичну значущість у філософії Льва Шестова знаходять миті, пов'язані зі свободою. Проблема свободи є в філософії Шестова основоположною. У книзі «Апофеоз безпідставності» він говорить: «Важка річ рабство, і велика річ свобода!» [5, с. 159]. Єдину можливість реалізації свободи і творчої мощі людської особистості мислитель знаходив у релігійному досвіді. Шестов вважав, що глибину життя не можна осягнути за допомогою тільки раціонального мислення. Він зазначав, що тільки одне добро безсиле впоратися з проблемами буття, необхідно шукати Бога, без якого життя стає безглуздим. Філософія Шестова одухотворена цим метафізичним богошуканням, справжність якого безсумнівна. Переважним інтересом у Шестова з самого початку виступає інтерес метафізико-етичний. 
Розум у нього виявляється найбільшим ворогом істини, оскільки істина йде від Бога, вона непорушна, а розум має властивість блукати і заходити в такі глухі кути, з яких вибратися вельми проблематично. Самі істини розуму, за Шестовим, поневолюють, а не звільняють думку. I звільнити ії може тільки просвіта Божественними істинами.

Шестов веде боротьбу проти розуму в ім'я релігійної віри і надлюдської свободи, які для нього збігаються. Протестуючи проти тиранії розуму, він говорить, що розум веде до необхідності, а віра веде до свободи. Шестов вважав, що в межах розуму можна побудувати науку, високу мораль, навіть релігію - але не можна знайти Бога. Він казав, що справжню живу віру замінили порожнім богослов'ям, яке зводиться лише до виконання обрядів.

Подібне висловлювання знаходимо у Лейбніца: «Всупереч наміру нашого божественного Вчителя, шанування Бога заміняють обрядами i вчення обтяжують формулами» [2, с. 52-53].

Шестов вважав, що людина завжди шукає свободи і рветься до божественного. Життя людини він вважав творчою справою. Безліч думок 3 цього приводу він висловив у книзі «Апофеоз безпідставності». Він пише: «Природа владно вимагає від кожного з нас індивідуальної творчості. Люди не хочуть цього зрозуміти, і всі чекають від філософії останніх істин, яких не було, немає і ніколи не буде. Істин стільки, скільки людей на світі... Хоче людина чи не хоче, рано чи пізно доведеться ій визнати непридатність всякого роду шаблонів і почати творити самій» [5, с. 181-182].

3 усіх цих міркувань ми можемо зробити висновок, що цінність творчості для Шестова стоїть нарівні зі свободою. I це не дивно, адже творчість безпосередньо пов'язана зі свободою. Тільки у вільній творчості людина може відкривати нові грані буття, а також пізнати саму себе, почути i відчути свою справжню сутність. Але це дано далеко не всім, надто ми залежні від чужої думки і нав'язаних нам пріоритетів. Шестов говорив 3 цього приводу: «Набагато краще було б, якби кожна людина мала свої власні думки. На жаль, цього ніяк не можна домогтися!» [5, с. 173]. 
Саме те казав і Ніцше. У творі «Так казав Заратустра» (розділ «Про вчених») він пише: «Мов ті, що стоять на вулиці й витріщаються на перехожих, сидять вони й витріщаються на думки, що прийшли в чужі голови» [4, с. 124]. I з цим важко не погодитися.

Заклик Шестова до необмеженої свободи мислення збігається для нього 3 щирою вірою. Шестов вважав, що згодом сама людина стане богоподібною і знайде владу над буттям, владу абсолютної творчості, якщо вона сповнена справжньої віри, для якої стираються межі між можливим i неможливим. Тоді і наше знання, за Шестовим, буде не тільки копіювати явища, а й творити події за своїм творчим натхненням, яке керується Божою волею.

Шестов, безумовно, має рацію в тому, що віра вище розуму, але віра без розуму була б сліпою. Основна проблема не в тому, щоб скасувати розум, замінивши його вірою, а в тому, щоб розум сам схилявся перед Богом, давши необхідний простір вірі.

Великим внеском Льва Шестова $є$ те, що він у своїх писаннях усіма силами стверджував цю ідею, він був упевнений в тому, що не закони природи, а саме закони логіки є найбільшими противниками свободи. За Шестовим, розумна істина поневолює, тому що у людини не залишається вибору, оскільки доводи розуму логічні, і людина стає безсилою перед цією логікою, вона змушена підкоритися їй. У примусовому характері істини Лев Шестов бачить зазіхання на свободу людини, і це насправді вірно.

Протести Шестова виправдані відносно тих, хто неправильно розуміє істину, хто матеріалізує істину, підміняючи іï авторитетом, наприклад авторитетом розуму. Тому що розум сам по собі може помилятися, і він повинен узгоджувати власні дії з об'єктивно сущою істиною, а не навпаки. За Шестовим, істина змушує ідеально, а не реально. Людина має свободу противитися істині, проте в такому випадку вона втрачає свою позитивну свободу, бо починає помилятися.

Шестов вважав, що трагедія людини в тому, що вона відпала від Істини 
і тепер часто пізнає іiї через скорботу. Однак одностороння істина приносить лише примітивне її розуміння. Справжня ж Істина є завжди істиною в дусі свободи. Вона пізнається не стільки розумом, скільки серцем, і тільки таке пізнання істини перетворює людину. Істина, пізнана тільки розумом, не була б повною істиною і поневолювала б, оскільки у людини не було б вибору, слідувати істині чи ні. Тоді вона усвідомлювала б, що повинна підкоритися істині, можливо, навіть всупереч своїй волі, бо в іншому випадку це означало б відхилення від неї. Сама істина постала б в якості примусової зовнішньої необхідності. Можна припустити, що саме тому Бог не постає перед нами в істинному образі, оскільки Він бажає, щоб ми пізнали Його серцем. Як говориться в Біблії: «Сину, дай мені своє серце» [1, с. 612] (Притч. 23, 26). I це дійсно так, бо без цього взагалі неможливо уявити свободу й пізнання.

Отже, за Шестовим, автономія людини від істини є необхідною умовою iii пізнання. Коли ж розум людини підноситься до вільного пізнання істини, вона знаходить справжню позитивну свободу.

\section{Висновки, перспективи подальших досліджень.}

Лев Шестов зробив величезний внесок в розвиток східноєвропейської філософської думки. Він вніс в неї цілющий струмінь свободи, показав нові шляхи пізнання істини. Йому вдалося довести необхідність розглядати проблему свободи волі в релігійному контексті. Він ясно показав, що без віри в Бога філософія не може бути повноцінною.

Лев Шестов вважає віру в Бога єдиним можливим шляхом пізнання, оскільки тільки вона може дати справжню свободу. Мислитель бачить прямий взаємозв'язок між вірою в Бога і філософією.

Таким чином, ми виявили основні екзистенційні положення, які Шестов намагався донести в своїй філософії. Але необхідно більш ретельно досліджувати творчість філософа, оскільки його ідеї носять актуальний характер, вони допомагають вирішити сучасні нагальні проблеми. 
Список використаних джерел

1. Библия. Книги Священного Писания Ветхого и Нового Завета. - М.: Российское Библейское общество, 1997. - 1376 с.

2. Лейбниц Г. В. Сочинения в четырех томах. Т 4. Опыты теодицеи о благости Божией, свободе человека и начале зла. - М.: Мысль, 1989. - 554 с.

3. Мотрошилова Н. В. Парабола жизненной судьбы Льва Шестова. // Вопросы философии. М.: Наука, - 1989, № 1, с. 129-143.

4. Ніцше Ф. Так казав Заратустра. - К.: Основи, Дніпро, 1993. - 415 с.

5. Шестов Л. И. Апофеоз беспочвенности: Опыт адогматического мышления. - СПб.: Авалонъ, Азбука-Аттикус, 2011. - 224 с.

6. Finkenthal M. Lev Shestov: Existential Philosopher and Religious Thinker HardcoverJune 9, 2010 Peter Lang Inc., International Academic Publishers; First printing edition (June 9, 2010), -203 p.

7. Martin B. A Shestov Anthology. Ohio University Press, 1970, - 328 p.

\section{References}

1. Bibliya. Knyhy Svyatoho Pys'ma Staroho i Novoho Zavitu. M.: Rosiys'ke Bibliyne tovarystvo, 1997. - $1376 \mathrm{~s}$.

2. Leybnits H. V. Tvory v chotyr'okh tomakh. T 4. Doslidy teodytseyi pro lasky Bozhoyi, svobody lyudyny i pochatku zla. - M.: Dumka, 1989. - 554 s.

3. Motroshilova N. V. Parabola zhyttyevoyi doli L'va Shestova. // Pytannya filosofiyi. M .: Nauka, - 1989, № 1, s. 129-143.

4. Nitsshe F. Tak kazav Zaratustra. - K .: Osnovy, Dnipro, 1993. - 415 s.

5. Shestov L. I. Apofeoz bezpidstavnist': Dosvid adohmatycheskoho myslennya. - SPb .: Avalon', Azbuka-Attikus, 2011. - 224 s.

6. Finkenthal M. Lev Shestov: Existential Philosopher and Religious Thinker Hardcover- June 92010 Peter Lang Inc., International Academic Publishers; First printing edition (June 9, 2010), $203 \mathrm{p}$.

7. Martin B. A Shestov Anthology. Ohio University Press, 1970, - 328 p.

\section{СВОБОДА КАК ОСНОВА ФИЛОСОФИИ ЛЬВА ШЕСТОВА}

\section{Т. Прудкая}

Философия Льва Шестова имеет тесную взаимосвязь с жизнью. Мыслитель считал необходимым уделять внимание наиболее животрепещущим вопросам, одним из которых является проблема свободы.

В статье анализируется феномен свободы как основополагающий принцип философии Шестова. Также отражены основные философские идеи мыслителя, анализируется взаимосвязь религии и философии в его творчестве.

Отмечается, что свобода для Шестова имеет центральное значение. Без нее нет и не может быть настоящей философии. При этом Шестов настаивает на том, что логика является основным противником свободы. В статье анализируется аргументация Шестова по этому вопросу.

Подчеркивается, что веру в Бога философ ставит выше разума, поскольку Бог - это Истина, а разуму человека свойственно блуждать.

Также выявлено, что Шестов считал невозможным рационально судить о смысле мироздания. Философ утверждает, что логика не может быть единственным способом познания бытия, он ищет другие формы проникновения в тайны мироустройства. Таким способом становится для него вера в Бога. Только вера дает возможность постичь тайны мира.

Шестов предвосхитил основные идеи позднего экзистенциализма. Философа 
волновали проблемы индивидуального человеческого существования, поиск выхода из безнадежности.

Ключевые слова: свобода, вера, Бог, истина, разум, логика, необходимость, философия.

\section{FREEDOM AS A BASIS PHILOSOPHIES OF LEV SHESTOV}

\section{T. Prudka}

The philosophy of Lev Shestov has a close connection with life. The thinker considered it necessary to pay attention to the most burning issues, one of which is the problem of freedom.

The article analyzes the phenomenon of freedom as the fundamental principle of Shestov's philosophy. It also reflects the main philosophical ideas of the thinker, analyzes the correlation of religion and philosophy in his work.

It is noted that freedom occupies the central position for Shestov. Real philosophy doesn't exist and can't exist without it. At the same time, Shestov insists that logic is the main opponent of freedom. The article analyzes Shestov's argumentation concerning this issue.

It is emphasized that the philosopher puts faith in God above reason, since God is the Truth, and the human mind tends to wander.

It was also revealed that Shestov considered it impossible to judge the meaning of the universe rationally. The philosopher asserts that logic cannot be the only one method of perception of the existance, he is looking for the other forms of penetration into the secrets of the world order. Exactly such method for him occurs the faith in God. Only the faith gives an opportunity to comprehend the secrets of the world.

Shestov anticipated the main ideas of late existentialism. The philosopher was worried about the problems of individual human existence, the search for a way out of hopelessness.

The philosophy of Lev Shestov deserves careful and detailed studying. But, unfortunately, not enough attention was paid to his work, that fact determined the relevance of this work.

The purpose of the study is to identify the importance of freedom as the basis of the philosophy of Lev Shestov, to reflect the central ideas of the thinker.

It is concluded that Lev Shestov considered the faith in God is the only possible way of perception, since only faith can give a true freedom. The thinker sees a direct correlation between faith in God and philosophy.

Keywords: freedom, faith, God, truth, reason, logic, necessity, philosophy. 